\title{
ANAL AND URETHRAL SPHINCTER ELECTROMYOGRAPHY IN SPINAL CORD INJURED PATIENTS
}

\author{
By R. Girard, P. Minaire, J. P. Casteran, E. Berard and M. Eyssette \\ Hôpital Henry Gabrielle, 69230 Lyon St-Genis-Laval, France
}

\section{Introduction}

ELECTROMYOGRAPHIC (EMG) examinations of the anal and urethral sphincters have been performed since 1955 (Petersen \& Franksson, 1955). Gradually, it has been introduced for paraplegic care by Timmermans et al. (1964), Isch et al. (1969), Bors and Porter (1970), Chantraine et al. (1973), Jesel et al. (1973), Diokno et al. (1976), Allert and Nakaarai. These authors have shown the possible contribution of this procedure for the understanding of urinary dysfunction in paraplegics. During 6 years we have performed this examination in paraplegics in a common and almost systematic way. At Henry Gabrielle Hospital, we are not using the intermittent catheterisation method, but the indwelling catheter.

Therefore we need to know the evolution of tonic state of bladder and sphincter muscles, in order to detect the re-appearance of reflectivity and the value of their synchronous contraction, to determine when to remove the catheter and begin the rehabilitation of reflex-micturition.

\section{Method}

The patient is in gynaecological position with an indwelling catheter. Bifilar needles are inserted according to the method described by Jesel et al. (1973) directly in the urethral sphincter through the perineum by help of an intra-anal finger in men and peri-urethrally in women. The anal needle is inserted in a second time. We use an Alvar Myodine Electromyograph and, recently, Medelec Equipment.

The electrical activity is tested at rest, with reflex and automatic mechanisms. A trial of voluntary contraction is always done. Then, combined EMG and cystometry are started to appreciate the variations of detrusor activity and their synchronisms with striated sphincters. If correct, the catheter is withdrawn and reflex micturition is undertaken. For cystometry are used successively cool and cold $\left(+4^{\circ} \mathrm{C}\right)$ solution of Vesirig. In case of hyperspastic sphincter a peri-urethral infiltration with Xylocain may be useful.

\section{Material}

From June 1971 to June 1977, I26 new paraplegic and tetraplegic patients ( 94 males and 32 females) have been explored at the end of the spinal shock when bedrest is over (6 to Io weeks after trauma). When not satisfactory the procedure is repeated later. On the whole I5I EMGs have been recorded. 


\section{Results}

\section{In Spastic Paraplegics}

Eighty-seven examinations in 66 para- or tetraplegics of which 5I were traumatic. The insertion of the needles and the anal dilatation with the finger provoke a hyperactivity of the sphincter that helps for their search. In a few minutes this activity slows down and it remains stable as already described by Chantraine et al. (1973) and Jesel et al. (1973): a continuous electrical activityresting activity - of slow frequency and with little potentials (between Ioo and $200 \mathrm{mV}$, not more), but apt to sudden variations with movements, cough etc. ...

The differences with normal sphincters are many: this resting activity very often disappears when the bladder is empty in the only urethral sphincter; the activity of both muscles is not completely the same; with complete lesions, no modification of this activity by voluntary contraction is to be seen; the reflex activity provoked by supra-pubic tapping or when exciting perineal reflexes is a little more important in intensity and in duration. This search allows one to test, for each patient, which cutaneous areas are the best to use for reflex micturition, mainly the supra-pubic area, but also anal or urethral regions, or other parts belonging to $\mathrm{S}_{3}-\mathrm{S}_{4}-\mathrm{S}_{5}$ roots; sometimes is seen a reflex activity from $\mathrm{SI}_{\mathrm{s}}$ stimulation with syncinesy of the big toe.

These findings must lead to the technique of rehabilitation, to locate the best areas for provoked micturition and to avoid contacts that could elicit a sudden contraction of urethral sphincter during micturition (like touching the penis with a basin for example).

The EMG examination explains the possibility of reflex micturition: the first tapping, supra-pubic or other, develops a reflex hyperactivity of both sphincters and a light pressure in the bladder (seen with cystometry), the second knock and the following exhaust gradually the sphincter activity which at the fifteenth or a the twentieth disappears completely for 2 or $3 \mathrm{sec}$. At the same time the contraction of the detrusor becomes stronger and a little urinary leak is obtained.

A vesico-sphincteric reflex starting from the trigone of the bladder with hyperactivity of both anal and urethral striated muscles does exist.

When the contraction of detrusor is too slow with no efficiency, the filling of the bladder with $200 \mathrm{ml}$ of a $4^{\circ}$ cold solution is carried out. Very often an effective contraction is obtained with a complete emptying of the bladder. The EMG shows a transitory hyperactivity that becomes intense and suddenly stops, allowing micturition.

\section{Particular Cases}

Cauda equina with 19 patients and 52 examinations: the EMG confirms the total or incomplete denervation, the reflex micturition is obviously of no value and micturition can be obtained by abdominal pressure. A repetition of EMG allows a control of denervation. Sometimes after I or 2 years polyphasic potentials appear as signs of reinnervation, and the techniques of micturition must be changed, with inclusion of voluntary exercises and triggering.

Paraplegics with fracture of TI2 or LI and flaccidity: 62 tests have been done in 39 complete flaccid patients. It is well known that the total destruction of the lower part of the spinal cord should not be evoked before being sure of the absence of reflectivity beneath the lesion. In this context, we saw nine cases with

I6/3-B 
clinical flaccidity in legs and perineum but with a strong reflex activity of sphincters. That caused for two of them damage of the bladder. Five times that activity appeared first only in the anal sphincter, and both muscles should be explored.

Case of P. ... Lucien, I8 years, TI2 fracture (12.06.73), flaccid paraplegic TI2. EMG: total denervation, micturition with hyperpressure. Eighteen months later infection and urinary leaking. Clinically, reflexes of knees and ankles and of perineum were not found.

EMG: light resting activity amplified by supra-pubic tapping, indicating the recuperation of reflex activity of the spinal cord in $\mathrm{S}_{3}-\mathrm{S}_{5}$.

Cystography: reduced capacity with thick wall of the bladder, stones and ureteral reflux and hypertonic urethral sphincter. Trans-urethral sphincterotomy, lithotrity were performed and reflex micturition was easily elicited with disappearance of reflux and englargement of bladder.

\section{Hyperspasticity of Urethral Sphincter}

The spasticity of the urethral striated muscle is sometimes unfavourable. EMG activity is always important. The rhythmic supra-pubic tapping does not stop it; the reflex micturition is not possible. After infiltration with periurethral Xylocain, a diminution of this excessive electrical spasticity is often seen.

\section{Sclerosis of the Bladder Neck or of the Urethral Sphincter}

The association of a clinical and radiological urethral obstruction, and a normal or light electrical activity in the striated muscle, excludes the hypothesis of striated spasticity and suggests a sclerosis. Diagnosis will be surgical and histological.

\section{Conclusions}

The EMG of the anal and urethral sphincters is a useful procedure in new spinal cord injured patients to detect the reappearance of reflex activity, and the existence of bladder dysfunctions. The combined cystometry with cool and cold solutions allows an approach to the synergistic function of the lower urinary tract. The EMG is a good guide and a good control to decide when to remove the catheter and how to rehabilitate micturition. Both sphincters must be explored.

\section{RÉSUMÉ}

L'EMG des sphincters a déjà été utilisé par différents auteurs. Comme eux, nous pensons que cet examien apporte des informations complémentaires très utiles. Notre expérience s'appuie sur I I I examens. On enregistre en même temps l'activité électrique du sphincter uréthral et anal. L'enregistrement est fait en état de repos, lors d'effort, de contraction volontaire et au cours de mécanismes réflexes ou automatiques (percussion suspubienne, recherche de réflexes périnéaux, toux.) et en fonction de l'état de réplétion de la vessie associé à une cystomanométrie au cours de la miction. Les résultats montrent que l'activité électrique des sphincters varie en fonction de l'état de réplétion de la vessie et qu'elle augmente par voie réflexe mais la répétition des stimulations tend à l'abolir en même temps que la pression intra-vésicale augmente, ces deux effets permettant la miction réflexe. Cet examen permet de confirmer l'existence des réflexes vésico-anal et vésicouréthral et l'activité des deux sphincters n'est pas toujours superposable. Cet examin permet le diagnostic de l'hyper-spasticité du strié, il détecte une faible activité volontaire dans les lésions incomplètes, il permet de détecter précocément le retour d'une activité réflexe du cône médullaire dans les paraplégies par fracture de Di2-Li qui représentent 30 per cent de notre série de 783 cas. 


\section{ZUSAMMENFASSUNG}

EMG der Schliessmuskeln wurde schon von verschiedener Verfassern beruht. Wie sie, denken wir dass diese untersuchung sehr nützliche Auskünfte bringt. Unsere Erfahrung beruht auf I5I Studien. Man registriert Urethral and Anal schliessmuskeln in ihrer electrischen Funktion. Die Registrerung is gemacht: in Ruhe, in Anstrengung, bei freiwilliger Muskelkontraktion und während selbstätigen oder reflex Mechanismus, bei einem Füllungszustand der Blase in der selben Zeit wie Blasenentleerung mit Zystomanometrie. Die Resultate zeigen dass die electrische Tätigkeit der Sphinkturen zunimmt wenn die Blase voll ist, und mit reflex Mechanismus. Wir bestätigen das Bestchen der Vesico-Anal und vesico-urethral Reflex. Mehr is die Tätigkeit de zweiten Sphinkter. Mit diese Untersuchung ist die Diagnose der striären Überspasticität möglich, sowie beim TI2-LI Paraplegiker (30 per cent von unserer Serie von 783 Fälle) die vorzeitige Entdeckung von reflex Tätigkeit. Diese Untersuchung erlaubt ein besseres Verständnis der Blasen und Sphinkterfunktionen beim Paraplegiker.

\section{REFERENCES}

Abramson, A. S., Roussan, M. S. \& D’Oronzio, G. (I966). Method for evaluating function of the neurogenic bladder. F. Amer. Med. Assoc., 195, 554-558.

ARChIMBAUD, J. P. (I974). Les dysfonctionnements vésico-sphinctériens neurologiques. Rapport au 68e congrès français d'urologie. Masson et Cie Edit.

BORS, E. \& PORTER, R. W. (1970). Neuro-surgical considerations in bladder dysfunction. Urol. Int., 25, I I4-133.

CASTERAN, J. P. (I977). L'électromyographie des sphincters strié, anal et uréthral. Thèse Lyon.

Chantraine, A., De Leval, J. \& Onkelinx, A. (I973). Motor conduction velocity in the internal pudendal nerves. New Developments in E.M.G., Vol. 2, pp. 433-438. Desmedt.

Diokno, A. C., KofF, S. A. \& ANDERson, W. (1976). Combined cystometry and perineal electromyography in the diagnosis and treatment of neurogenic urinary incontinence. F. Urol., II5, I6I-I63.

Girard, R., Berard, E., Minaire, P., Eyssette, M., Leriche, A. \& Bourret, J. (1976). Place de l'électromyographie des sphincters dans la rééducation vésicale des paraplégies par fracture de Di2-Li. Lyon Médical, 236, 391-392.

Isch, F., Bollack, C., Jesel, M., Rieffel, F., Masson, J. C., Fresnel, P. L. \& Pietri, J. (1969). Place de l'électromyographie du sphincter strié urétral dans les explorations de l'appareil urinaire. F. Urol. Nephrol., 75, 413-423.

Jesel, M., IsCH-Treussard, C. and IsCH, F. (Karger, Basel I973). Electromyography of striated muscle of anal and urethral sphincters? New Developments in E.M.G., Vol. 2, pp. 406-420. Desmedt.

LERICHE, A. (I973). La maladie du sphincter strié de l'urètre. Thèse Lyon.

Petersen, I. \& FRANksSon, C. (I955). Electromyographic study of the striated muscles of the male urethra. Brit. $\mathcal{F}$. Urol. 27, I48-153.

Timmermans, L., Diverse, P. \& Chantraine, A. (1964). Premiers renseignements de l'examen électromyographique du sphincter strié de l'urètre humain. Acta Urol Bel., 32, 425-434. 